\title{
京都市中心部における併用住宅の住み方と 改善の経歴に関する研究 \\ A STUDY ON CAREERS OF DWELLING AND IMPROVEMENT OF HOUSES WITH WORKING SPACE IN CENTRAL AREA OF KYOTO
}

\author{
清 水 肇*1, 坂東亜希子*2, 片方 信 也*3, 小伊藤直哉*4, 岩 崎 滋 彦*5, \\ 古谷 勲*6, 杉谷久美子*4 \\ Hajime SHIMIZU, Akiko BANDO, Shinya KATAGATA, Naoya KOITO, \\ Shigehiko IWASAKI, Isao FURUTANI and Kumiko SUGITANI
}

\begin{abstract}
In Kyoto's central area there still exist many traditional style houses with working space. This case study shows that three typical house types in the research area are $1,1 * 2$ or $1 * 3$ rooms plan type with 1 or 2 rooms workshop, $2,1 * 3+1$ rooms plan type with office or store, $3,1^{*} 3+1$ rooms plan type with detatched working place. Plan types with "tooriniwa" are improved by residents, succeeding the characteristics of original plans. Limitation of improvements depend on plan type, width of sites and combination type of living space and working space.
\end{abstract}

Keywords :house with working space, plan type of house, house improvement, central district of a city

併用住宅、住宅型、住宅改善、中心市街地

\section{1、研究の目的と方法}

\section{(1) 既存研究の検討}

本研究は、京都市中心部の併用住宅の改善経歴を対象 としている。このような研究対象に関連する既存研究の 特徵と本研究の視点との関係を以下に述べる。

都市の併用住宅については、近年ではまとまった研究 報告は少ない。1970年代までの研究の中には京都市内の 事例分析や住工混合地域の併用住宅を取り上げたものが ある。これらの研究の中で、併用住宅は零細自営業者の 住宅であることが多いことを背景に、「時間的、空間的 な『職住混合』」の矛盾があることが指摘されている。 また、「居住立地限定階層」論も「職住近接を余儀なく される階層」の存在を指摘し併用住宅や職住関係を見る 上での視点を与えている(ㅊ:1)。このように併用住宅の 生活や職住近接は実態として否定的な側面があることが 言われ、現在でも未解決の問題があると考えられる。し かし、これらの指摘を改めて整理してみると、問題が生 じるのは、(1)長時間或は不規則な労働時間、(2)居住空間
の広さ・構成の問題や仕事場から生活空間への環境上の 悪影響等の問題がある場合である。逆に言えば、これら の状況についての改善がなされることを仮定すれば、併 用住宅が本来持っている職住近接という利点を生かせる 可能性がある。(1)の労働条件の問題は空間的問題ではな いのでここでは触れないが、(2)についての空間的改善の 余地を本稿は取り上げる。

京都市中心部の住宅は伝統的な併用住宅の代表的なも のの一つとして知られているが、近年の研究でその併用 住宅としての住み方に着目したものは少ない(ì2)。 なお、京都市は日本の大都市の中では特に中心部の住宅 の密度が高く併用住宅も多いという際だった特色がある と同時に居住地空洞化も進みつつある (i: 3)。併用住宅 は、住商工の機能の共存の比較的長い歴史を持つ市街地 で職住近接の状態を支えてきた条件の一つであるが、本 稿はその実態分析により市街地における仕事場と居住空 間とのあり方を考察し、市街地整備の課題を導こうとす るものである。

\footnotetext{
*1 琉球大学教養部 講師・工修

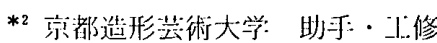

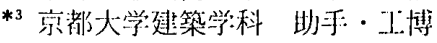

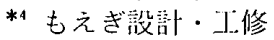

*5 日本没計・王修

*6 樍水ハウス・I修
}

Lecturer, Division of General Education, Univ. of the Ryukyus, M. Eng.

Research Assoc., Kyoto Univ, of Arts and Design, M. Eng.

Research Assoc., Dept. of Architecture, Kyoto Univ., Dr. Eng.

Moegi Sekkei, M. Eng.

Nihon Sekkei, M. Eng.

Sekisui House, M. Eng. 
また、本稿は特に住み手による住宅改善に着目する。 市街地整備研究の分野では、住宅改善の実態に着目する ことは、住み手の要求を把握し、市街地改善の可能性を 考察する上で有効な方法として位置付けられ調査研究が 蓄積されている。本稿はそれらの研究の「住み手の改善 努力を生かし得る市街地整備」の考え方 (住4) と共通す る視点を持つ。ただし、これまで扱われてきたのは「狭 小宅地住宅地区」などと呼ばれる小規模住宅の集中地区 が多い。これらの場合「改善」の中身は主に建て替えに

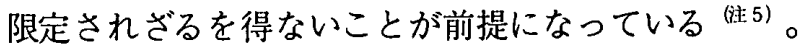
これに対して本稿で扱う都市中心部の歴史的市街地では 多様な敷地規模、住宅形式が存在しており改造や増築な どで住要求の実現を図る事例が見られる。歴史的市街地 でこのような改造等を取り上げた研究には、今井町の歴 史的居住地での調查研究があり、近年では金沢市での調 查研究が住宅型の成立と変容の要因について言及してい

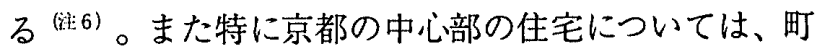
家の空間構成の実態がしばしば取り上げられてきたが (ii:7)、住み手の改善による空間構成の変化を中心的に 取り上げた研究までは展開していない。

以上述べたように、同様のものを対象とする既存研究 で充分に展開されていない(1)併用住宅への着目、(2)住み 手の改善経歴への着目、という $2 つ の$ 視点からの分析を 本稿では行なう。

\section{(2) 研究の目的}

京都市中心部の木造併用住宅の多い地区をケースス夕 ディとして取り上げることにより、併用住宅の住み方と 改善経歴の特質を明らかにすることが本稿の目的である。 住宅改善の中には、住宅の空間構成の特質を基本的に踏 就しながら行なわれるものと、建て替えや大規模な改造 によるものとがあるが、本稿は前者の範囲までを扱う。 すなわち、後者も含めて地域の住宅の改善を展望する中 での一段階として、本稿は既存の木造併用住宅形式のも のの改善経歷を取り上げる。

\section{（3）調査の概要と研究の方法}

調査対象地区は、中心業務地区に近接しているが友禅 染色業関係の木造併用住宅が多く見られて比較的人口密 度の高い一帯から選んだ。友禅染色業の集積の一つの中 心である西洞院通に近く比較的人口密度の高い町の中の 2 町を対象とした（図一1） (a:8)。京都の旧市街地の 2つの街区パターンである正方形街区、長方形街区の両 方にまたがっており多様な敷地パターンを含んでいる。

対象は地区内の全ての戸建て又は長屋建て建物の利用 世帯とした。この地区では現在専用住宅や非居住建物で あっても以前併用住宅であった可能性もあるのでそれら も調查対象に含めた。今回の調査は町家、長屋と通称さ れる在来型の市街地住宅の分析を主眼とするため、それ
らが戸建てで建て替わったものまで対象に含め、共同住 宅は調查対象としなかった (隹9)。調查は1991年12月〜 1992年2月の間に行ない、地区(1)で52事例中 31 事例、地 区(2)で34事例中28事例に対する調査が実施できた（残 りは拒否又は期間内の調查不能）。うち居住用は地区 (1)で28事例（うち併用住宅14事例）、地区(2)で22事例 (うち併用住宅18事例) である。

調査方法は観察と住み手または建物利用者への聞き取 りによる。項目は、住宅の空間構成とその使い方の現状 とこれまでの変遷であり、改善経歴の内容とそれに関わ る住要求である。現状は観察によるプラン採取と聞き取 り、改善経歴（原則として1945年以降または来生後）に ついては聞き取りを行った。

この調査をもとに、ます敷地と住宅型の概要を整理し、 続いて併用住宅の住み方の特質と改善経歴を分析する。 改善経歴の分析は、住宅の空間構成の類型、すなわち住 宅型ごとに進め、この地域の在来の住宅型が持つ併用住 宅としての特質とその可能性及び住み手の要求と改善行 為の関係について考察した。

なお、先に述べたように現在非居住用途や専用住宅で も以前併用住宅として使われたものが多く空間構成の共 通性も高い。そこで分析では敷地と平面構成全般につい ては全事例（59世帯、60建物、1世帯は2敷地にまたがる） を扱い、併用住宅の分析では現在併用住宅である31世帯 を対象とした。さらに、改善経歴については現在木造の 25事例を中心に分析した。

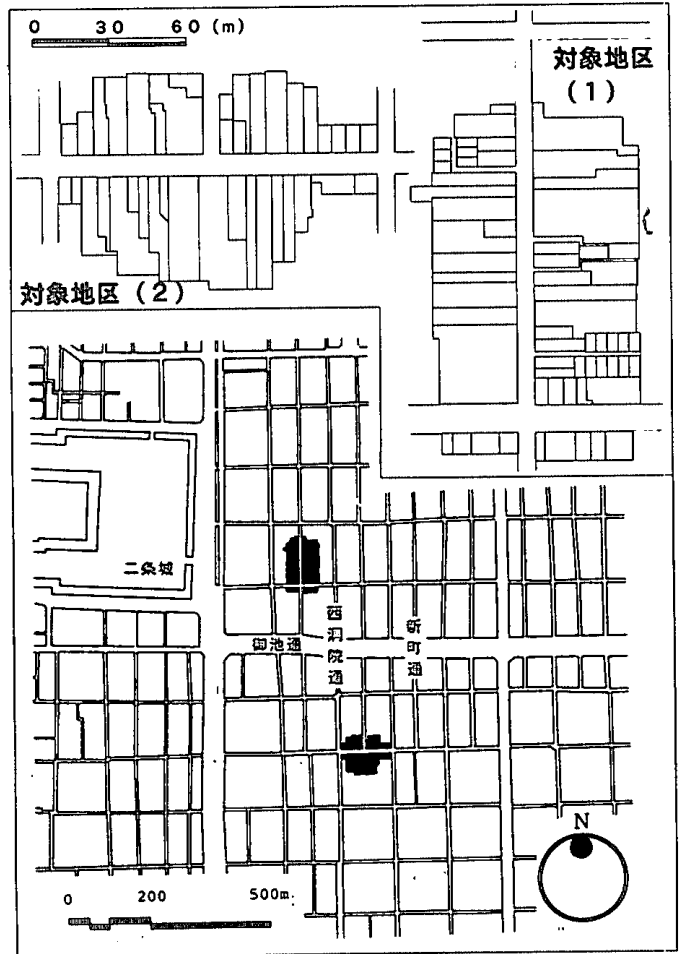

图一 1 調查対象地区の位置と敫地割 


\section{2、敷地と住宅型}

\section{（1）敷地の形態}

京都市中心部の敷地割りは平安京の町割りを原形とし て、その改变の結果として存在している。敷地の分割・ 統合過程と形態については既存研究で詳細に扱ったもの があるので (i.10)、ここでは住宅型分析の前段として対

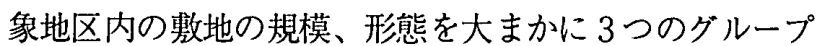
に分けるにとどめる。すなわち、図一2の3つの敷地夕 イプがある。調査対象の60の敷地のうち57は 3 つのどれ かにあてはまる (:1:11)。さらに面積との関係をみたのが 表一1である (i:12)。

<I >敷地（18事例）は路地に面した敷地であるが、 角地付近にもほぼ同様のものが見られるのでこれに含め る。奥行き $8 \sim 10 \mathrm{~m}$ 、面積は $40 \mathrm{~m}^{2}$ 台のものが多く、最も 多い間口は 2 間 $(3.8 \mathrm{~m}$ 強、12事例) である。

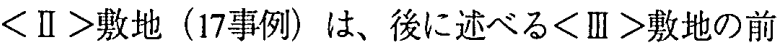
半分か後半分の形をしたものである。奥行きは $15 \mathrm{~m} \sim 20 \mathrm{~m}$ 程度までの幅があり、面積は $60 \mathrm{~m}^{2}$ 台と $90 \sim 100 \mathrm{~m}^{2}$ 程度の ものの 2 つのグループが目立つ。間口はほほ、2 3 間 $(3.8 \mathrm{~m}$ 強 $\sim 5.7 \mathrm{~m}$ 強、 2 間 $=7$ 件、 25 間 $=5$ 件、 3 間 $=$ 5件）の間にある。

$<$ III > 敷地（22事例）は、通りからほぼ街区中央付近 までの奥行きを持つ敷地である。街区形状 (i:13)により 奥行きは約 $30 \mathrm{~m}$ と約 $40 \mathrm{~m}$ の場合がある。面積は $160 \mathrm{~m}^{2}$ か ら $240 \mathrm{~m}^{2}$ の間に11事例が集まっているが、それを越える ものは規模のばらつきが大きい。間口は 2 間に 9 事 例、規模の割に狭い 2 間も 5 事例ある。一方、3.5間が 8 事例、 4 間以上が 5 事例あるのがく I > 敷地と異なる。

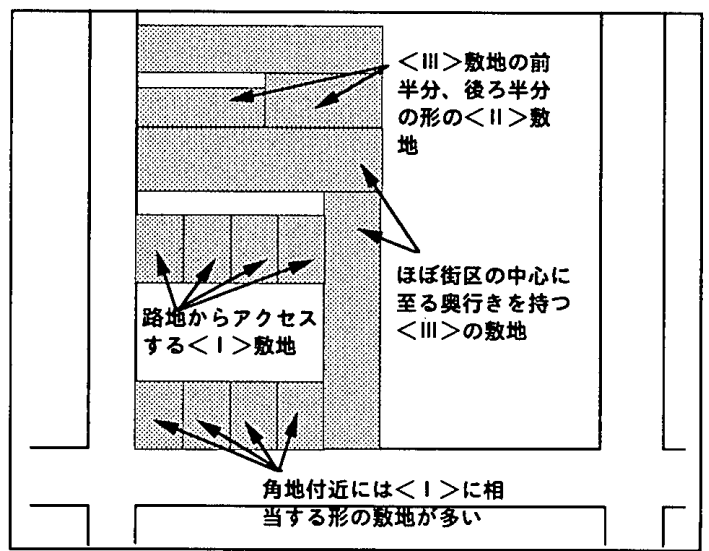

图一2 敖地形態の分類

\section{（2）住宅型}

52事例（160）は木造 2 階建てであり、そのうちく I > $<$ II $><$ III $>$ 敷地の 49 事例はもともと通り庭を持った平 面構成である。そこで既存調查で用いられてきた段と列 による平面の記述方法を用い調查事例の空間構成を分類

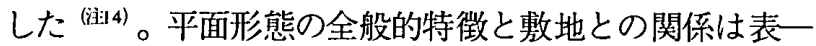
2のとおりであり、以下のことが読み取れる。

(1)離れを持たないもの25事例と持つもの22事例に大別で きる。<I > 敷地は 1 列 2 段の典型的な長屋の形式に対 応し、<四 > 敷地は離れを持つものが典型になる。＜II > 敷地は離れを持つ場合、持たない場合に別れる。

(2)主屋の形式はＩＩ＞敷地では 1 列 2 段である。 $<$ III > 敷地では 1 列 2 段が少数あるが特に 1 列 3 段が多 い。離れを持つものに主屋 4 段が 5 事例あるが、これは 裏に増築した 1 事例を除けば 3 曽程度の小さな中の間が 2 室あるもので構成としては 3 段に近い。1+2+2段 のような 3 棟以上のものは 2 事例にとどまった。離れは 1段か 2 段構成だが平面構成の規則性はあまり見られな い。

(3) 3 間以下の間口の敷地では基本的に 1 列形式になる。 2 列以上のものは、大型町家の一つの典型として知られ る 2 列型プランが 2 事例、2 1 化の改造によりほぼ2 列型プランになったものが 1 事例ある。

(4)なお平面分析の際には、裏につくられる土間形式の別 棟の作業場を記述の対象に含めなかった。これは主屋と 離れとの間の場合と離れの奥にある場合とがあるが、い

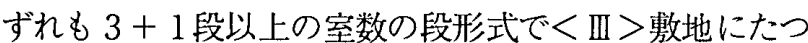
( 5 事例)。

以上の概観加 1 列 2 段型（<I > 敷地）、1列 3 段 型（主に<II $>$ 敷地）、1列 $3+1$ 段型 $(<$ II $><$ III $>$ 敷地）の3つがこの地区の住宅型の典型とみなせる (i:15)。

\section{3、併用住宅の住み方と改善経歴}

\section{（1）住宅内の仕事場の形式}

本項以降は調查事例の中の併用住宅を対象として、仕 事場を持つ住宅の住み方と改善経歴の特質に関する考察 を進める。

対象地区は友禅染色業の集積地域の中にあり、17事例 (131）が染色業関係（製造15、卸売2）である (il116)。他 の繊維関連流通に関わる業種を加えると20事例になる。

表一 1 教地タイプと面積

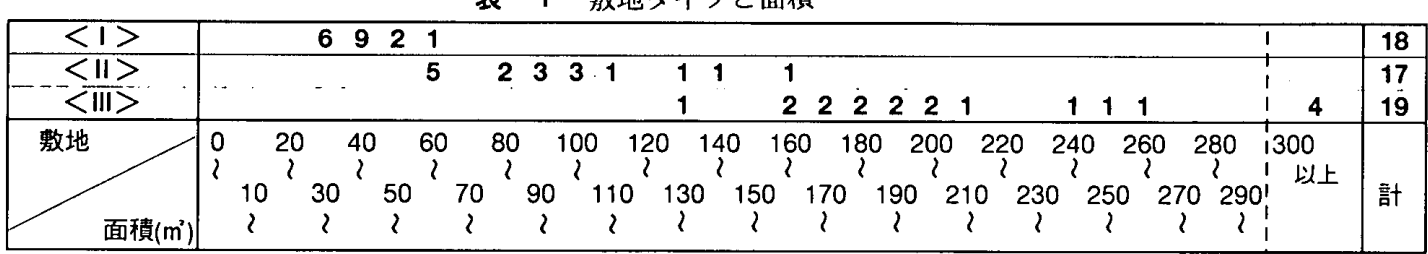

（数字は敖地の件数を表わす。くその他〉の数地の 3 件、敷地面䅡を確定できなかったくII > 敷地の 1 件と <III>敖地の 2 件を除いた54敷地について表を作成した。) 
他は釜製造 2、そして小売を含めたサービス業である。

仕事場に割り当てられた空間と家族の生活空間の関係

(以下、「仕事場」と「居住空間」とし、居住空間内の 部屋を「居室」とする）を整理すると以下の 3 つの形式 に大きく分けられる（図一3）。

(1)居住空間の一部に 1 室の仕事場か割り当てられた形式 のもの。主として手工芸的性格の強い製造業の場合であ る（「1室仕事場型」と呼ぶことにする）。人の出入り を優先させて 1 階表の部屋を使うものが多いが、作業環 境を重視して 2 階裏か 2 階表の部屋を使う場合もある （いずれも主屋内）。1室の専用仕事場の隣室を居住空 間と転用しつつ補助的に使う事例も見られる（「連続室 仕事場型」とする）。

(2)主屋内で 1 階と 2 階の使い分け、あるいは主屋と離れ で使い分けることにより、仕事場と居住空間とのブロッ クとしての区別が明確なもの。家族以外の人の出入りの 多い製造業、卸売業、サービス業等の場合の形式である （「工房・事務所型」とする）。

(3)居住空間から独立した仕事場専用の棟をもつもの （「別棟仕事場型」とする）。染色業では、機械や水の
使用のために居住空間と分離する必要のある業種がある。

表一 3 のように業種ごとに見ると染色関係製造業は 1 室仕事場型と別棟仕事場型に対応する。前者に多い職種 は染色補正、刺紼、紋描き等であり、後者は色染、湯の し等である。一方、工房 ·事務所型は卸売業と各種のサ一 ビス業に対応している。

仕事場の形式と住宅型との関係を見たのが表一 4 であ る。1 室仕事場型と連続室仕事場型は離れを持たない住 宅型に多く、工房・事務所型と別棟仕事場型は離れを持 つ住宅型に多い。1列 2 段型では工房・事務所型の使い 方は困難であるし、1 列 3 段型で 1 例だけみられる工房 · 事務所型は食事室を仕事場と兼用している。つまり、離 れを持たない住宅型では 1 室又は連続室仕事場型以外は 難しい。このように住宅型、業種、併用形式の対応関係 は強く現れており、く1列 2 段または1列 3 段型住宅で 手工芸性の強い製造業を営む 1 室または連続室仕事場型 $>$ 、<1列 $3+1$ 段型住宅で卸売や各種サービス業を営 む工房・事務所型 $>、<1$ 列 $3+1$ 段型住宅でやや広い 仕事場の必要な製造業を営む別棟仕事場型>、以上の 3 つのタイプが調査地区内の典型的な併用住宅のパターン

\begin{tabular}{|c|c|c|c|c|c|c|c|c|c|c|c|}
\hline \multirow{4}{*}{ 住宅型 } & \multicolumn{9}{|c|}{ 末造 } & \multirow[t]{4}{*}{ 非松造 } & \multirow[b]{4}{*}{ 鼓 } \\
\hline & \multirow{2}{*}{\multicolumn{3}{|c|}{$\frac{\text { 触九を持たたな }}{\text { 1列 }}$}} & \multicolumn{5}{|c|}{ 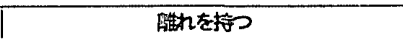 } & \multirow{3}{*}{ その他 } & & \\
\hline & & & & \multicolumn{4}{|c|}{ 1列 } & \multirow{2}{*}{$\begin{array}{c}2 \text { 2列 } \\
3+1 \varepsilon^{2} \\
\text { または } \\
3+2 \text { 段 }\end{array}$} & & & \\
\hline & 2段 & 3段 & 4 & $\begin{array}{l}2+1 \text { 股 } \\
\text { またたt } \\
2+2 \text { 段 }\end{array}$ & $\begin{array}{l}3+1 \varepsilon^{2} \\
\text { または } \\
3+2 \varepsilon^{2}\end{array}$ & 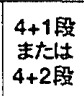 & $\begin{array}{l}\text { ₹の他 } \\
\sigma \\
\text { 段描成 }\end{array}$ & & & & \\
\hline$\Delta>$ & 15 & & & & & & & & 2 & 1 & 18 \\
\hline$\Delta 1>$ & & 7 & & 4 & 1 & 1 & & & & 4 & 17 \\
\hline$\Delta \| 1>$ & & 2 & 1 & & 8 & 4 & 1 & 3 & & 3 & 22 \\
\hline ₹の地 & & & i & & 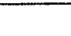 & & & & 3 & & 3 \\
\hline Ft & 15 & 9 & 11 & 4 & 9 & 5 & 1 & 3 & 5 & 8 & 60 \\
\hline
\end{tabular}

菽一3 仕事埸形式と業種

\begin{tabular}{|c|c|c|c|c|c|c|}
\hline 徔程 & & 皓 & 䇴宽（缕 & 皆を含む) & 小孛 & ot \\
\hline 仕弱场 & 染色器孫 & 经色闒係以外 & 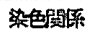 & 染色辟崕以外 & サービス & of \\
\hline 1 室仕研垉型 & 6 & & 1 & 1 & 3 & 11 \\
\hline 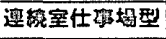 & 3 & & & & & 3 \\
\hline 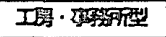 & 2 & 1 & 1 & 3 & 5 & 12 \\
\hline 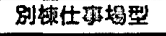 & 4 & 1 & & & & 5 \\
\hline gt & 15 & 2 & 2 & 4 & 8 & 31 \\
\hline
\end{tabular}

跈一4 住宅型と仕事場形式

\begin{tabular}{|c|c|c|c|c|c|c|c|c|c|c|c|c|}
\hline & \multirow{3}{*}{\multicolumn{4}{|c|}{ 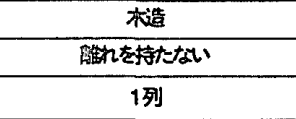 }} & & & & & & & \multirow[t]{4}{*}{ 非本造 } & \multirow{4}{*}{ 淂 } \\
\hline & & & & & \multicolumn{5}{|c|}{ 踾九を持つ } & \multirow{3}{*}{ zo地 } & & \\
\hline & & & & & \multicolumn{4}{|c|}{ 1列 } & \multirow{2}{*}{ 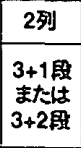 } & & & \\
\hline & 2段 & $\begin{array}{l}\text { 特㘧な } \\
も \sigma ゙\end{array}$ & 3段 & 4段 & 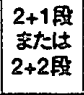 & 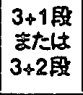 & $\begin{array}{c}4 \bowtie 1 \\
\text { または } \\
4+2 \varepsilon^{-}\end{array}$ & 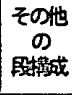 & & & & \\
\hline 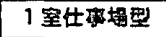 & 2 & & 4 & & 2 & & & & & 1 & 2 & 11 \\
\hline 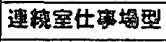 & 1 & 1 & 1 & & & & & & & & & 3 \\
\hline 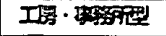 & & & 1 & & & 2 & 2 & 1 & 2 & & 4 & 12 \\
\hline 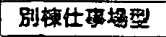 & & & & & & 3 & 8 & & 1 & & & 5 \\
\hline Bt & 3 & 1 & 6 & 0 & 2 & 5 & 3 & 1 & 3 & 1 & 6 & 31 \\
\hline
\end{tabular}

**1 つの路地内の 1 列 2 段型を 2 件合わせて利用しているもの 1 例

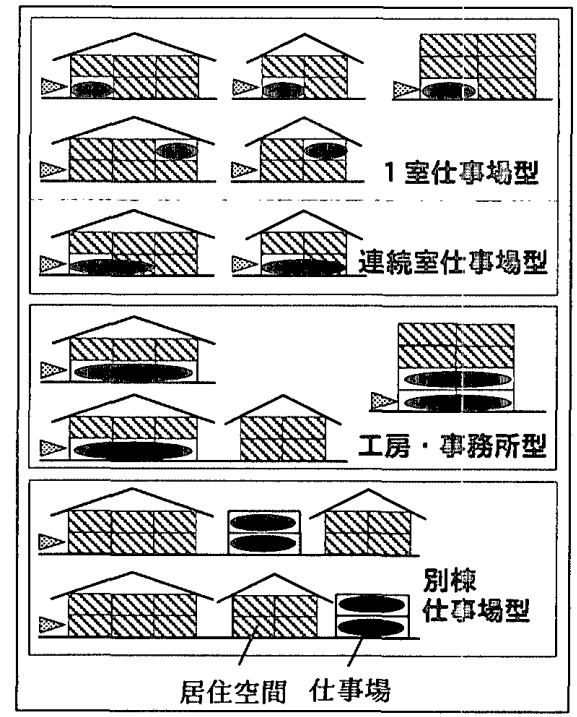

圈一３併用住宅の仕事場形式 
として見いだされる。

\section{（2）併用住宅の改善箅所}

1945年以降あるいは来住時以降に確認される住宅平面 の変化を伴う改善行為を木造25事例の全てについて分類

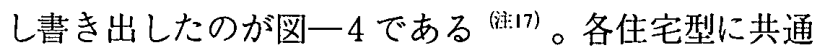
して1945年以前では、ほほ全てが土間の通り庭（上部は 吹抜け）を持ち、大多数は軒高が低く 2 階の表と裏の天 井高が他の部屋より低かった。このような空間棈成のも のを各住宅型の「原形」と考え分析を進める。まず、改 善箇所ごとに概要を述べる。

まず、全体を通じて件数が多いのは通り庭に関わる改 善である。通り庭型プランのもの24事例のうち17事例で 見られた。1階の土間と 2 階の吹抜け部分に床を張るの が典型である。この時に階段位置を変更したものもある。

他に主屋部分に関しては 2 階の改造やミセの間、奥の 間の拡大による面積増がある（10事例）。軒高を高くす る（「中2階」を「本 2 階」にすると通称される）こと で2階の実質的な居室面積を増やせる。ミセの間、奥の 間は微小な拡大のケースはあるが、段構成の変更までと もなうものは1事例のみであり、庭への建て詰まりは一 般には行われていない。

離れに関わる改善が 9 例ある。内容は蔵から離れへの 改装や建て替え、既存の離れの部屋の増築である。現在 離れを持つものは14例であるからその3分の2が拡大を経 てきたものである。

上記以外の主屋に関わる改善としては、主屋内部の部、 屋の用途変更に伴うものがある。居室を仕事場やガレー ジに変えるのに伴って部屋の接続関係等を変える場合で ある（ 7 事例）。

他には別棟の仕事場の増築（2 事例）、2 戸を 1 戸と して利用したもの（2 事例）がみられる

なお、一般には改善行為の可能性は所有関係に強く規 定される面があるが当地区では借家は併用住宅のうち 4 例のみであり、また借家でも改造が活発なものもあるの で所有関係との関係の分析は割愛する (i:18)。

\section{（3）改善の目的と内容の分析}

各改善行為をその目的ごとに整理すると以下のように 分けられる。まず、(1)仕事場、(2)居住空間、(3)両者の相 互関係に関する改善の3つに大別できる。ただし、(3)の 内容のほとんどは後述するように動線に関わるものであ り、その際に(2)の一部である居住空間内の動線に関わる 改善を伴う場合が多く見られた。従って、動線に関する 改善はまとめて扱う必要がある。以下の項ではこのよう な順番で改善経歴の分析を記述する。

\section{i ）仕事場の改善}

仕事場の改善は、仕事場の面積の拡大または仕事場の 空間構成の変更である。これは 8 事例で確認できた。都 心部の併用住宅の割に代事場の拡大事例が少ないのは1
室仕事場型のような手工芸的な小規模製造業の数が多い 地区であるためと思われる。また、仕事場拡大を理由と した非木造への建て替えも 2 事例だけである。

仕事場の位置は主屋 2 階だけのものが 5 事例（主に 1 室仕事場型）、主屋の奥の別棟が 5 事例、それ以外の 15 事例は 1 階の表の間（ミセの間）を含んだ主屋の表側で ある。主屋 2 階の仕事場は小規模なものが多く拡大した 事例は見られないので、仕事場拡大のパターンとしては、 別棟仕事場型で仕事場まわりへの増築（2事例）、主屋 の中では仕事場周辺の居室を仕事場に用途を変えていく

（6事例）ものがある。別棟仕事場の拡大は主屋に直接 の影響は及ほさないし、主屋内の仕事場拡大は部屋の用 途を変えるだけで行なわれる。つまり、通り庭の改造や 増築など主屋の大きな改造を伴っていない。

\section{ii) 居住空間の改善}

居住空間の改善の内容は(1)居室の数を増やす、(2)居室 の面積を増やす、(3)居室間のつながりを改善する（動線 の項で後述）、の3つが見られる。

居室の数を増やす改善は主に離れの改造により行なわ れている。

居室の面積を增や寸改善は、主に主屋内で通り庭とそ の上部の吹抜けに床を張ることで行なわれている。主屋 の「本 2 階」化も、天井が低く物置等になりやすい部屋 を利用しやすくする点で居室の数を増やす意味合いがあ る。このような改善は大多数の事例で見られ、現在は原 形の空間構成を残すものは少数になっている。主屋は、 戦前から既に「本 2 階」になっていたものもあるので、 現在「中2 階」の形を残すものは 4 事例しかない。通り 庭も土間の形を残すものは 5 事例だけになっている。

なお、この地区の併用住宅には住み込み従業者の居住 空間があった時期がある。この実態は人数や住み方の変 化が大きく今回の調査の聞き取りでは詳細な状況の把握 は困難だったが、1945年以降で少なくとも8事例で住み 込み従業者がいた。それ以前はもっと多かったと推定さ れる。これは必ずしも規模の大きい住笔だけでなく離 れのない住宅型の事例にも見られる。住み込み従業者は 3 名以上で4.5畳程度の部屋を使っていたり 2 階表の天 井の低い部屋や仕事場、台所の一部を寝室にしていなな ど、かなり厳しい条件で居住していた事例が多い。これ らは1975年の時点ではなくなって現在は見られない。住 み込み従業者の使っていた部屋も「本 2 階化」などによ り居室を増やしていく際に活用されている。

iii）仕事場と居住空間の関係の改善

冒頭で述べたように既存研究の指摘によると、併用住 宅には「職住混合」の問題が存在することがある。これ は空間的、時間的な両者の混合状態によるものだが、空 間的に「職住混合」が問題となる場合を整理してみると (1)闲空間の米用、(2)仕事場加ら居住空間への環境上の悪 


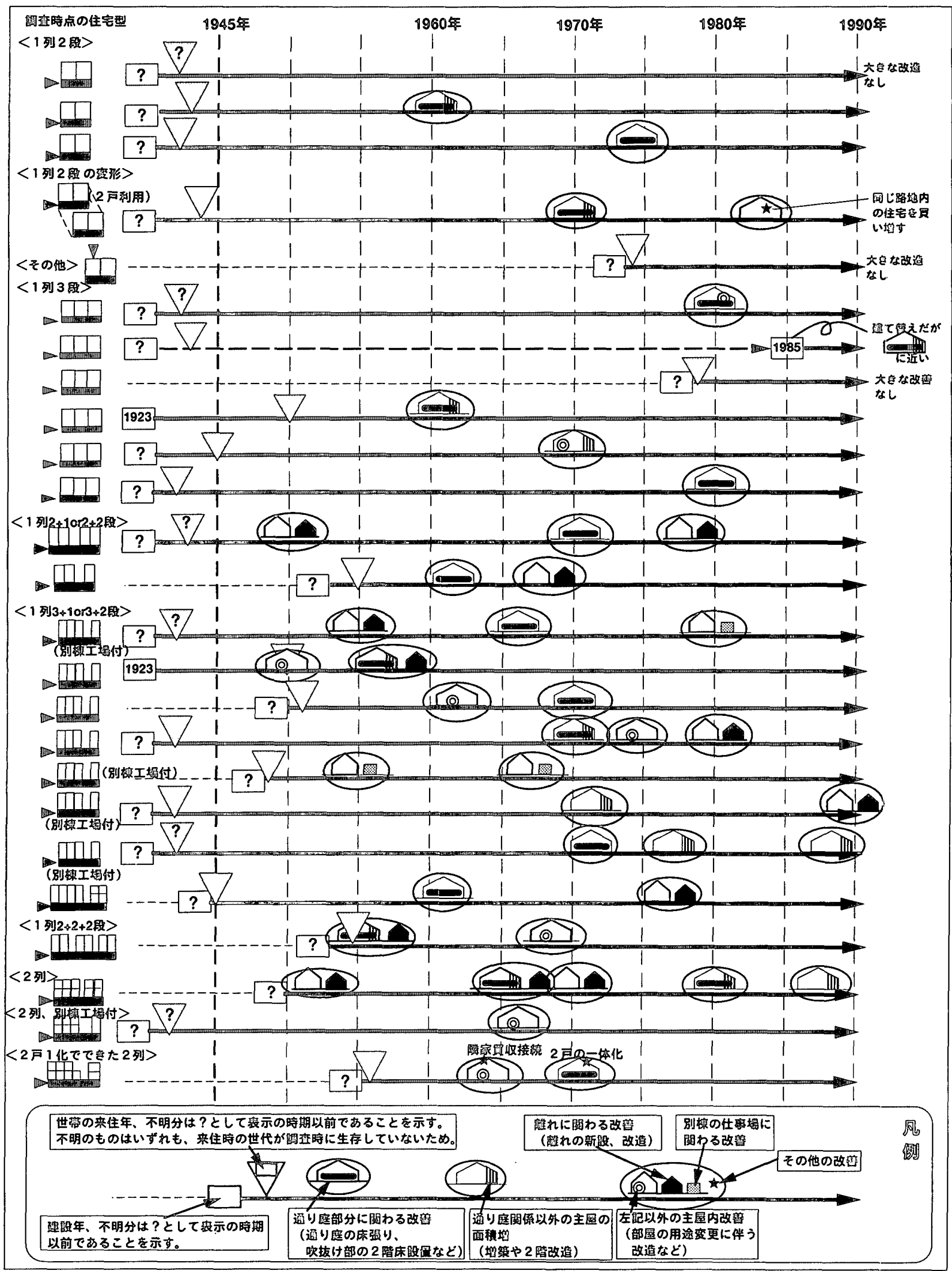

图一4 木造併用住宅事例の改善経歴 
影響、(3)両空間の動線が交わることによる混乱の3つが 考えられる。

調査事例においては、(1)の空間の兼用状態は現在、過 去ともに少数 (3 事例) でしか見られず、これを課題と した改善も特に見られなかった。当地区の場合、製造業 関係では道具や設備の設置のため、卸壳等の流通関係で は商品置場として仕事場は専用化する必要性が強い。

(2)の環境上の悪影響としては仕事場での水、薬品、燃 料等の利用や騒音に上る物理的影響がある。この問題が 生じやすい業種は引き染など土間形式の仕事場で行なわ れており、別棟仕事場の形式になっているので居住環境 に直接悪影響を及ほす事例は見られなかった。この点を 課題とした改善も特に行なわれていない。一方、1室仕 事場型の場合の半数（4事例）は建具による簡単な仕切 りで仕事場を区切っていたり、連続仕事場型で両者の区 切りが時間によって変わる事例もある。このように、職 種と仕事場形式次第では、仕事中に容易に休息できるな どの職住近接の利点を生かすものもある。

結局、改善の対象となることが多かったのは両者の動 線の交わりの問題である。

\section{iv）動線の改善}

仕事場と居住空間のつながり及び居室間のつながりに 関する課題に対する改善は、(1)寝室など通り抜け動線が あることが望ましくない部屋の通り拔けをなくす、(2)仕 事場の動線と居住空間の動線を区分する、の2つの目的 があるが、両者とも通り庭及び階段という全体の接続空 間と関係が強いため、同時に実現されることが多い。原 形での階段位置は、1 列2段型主屋のミ七の間、1列 3 段型主屋の中の間でどちらも通り庭の反対側にある。こ の場合、1階のミセの間か中の間の仕事場を通り抜けて 2 階や奥の間の居室に入ったり、2 階で階段に接する居 室に通り抜け動線が生じる状態になりやすい。このよう な問題の生じ方と改善について以下、典型的な住宅型ご とに整理する。なお、記述に抄ける1階の「通り庭部分」 とは現在または過去に通り庭のあった場所であり、調査 時点では多くの場合板の間になっている。

1 列 2 段型 (4 事例) では、1 事例を除いて原形の通 り拔け動線が残っている。この理由は、(1)奥行きが短い ために奥の通り庭部分が台所でふさがりミセの間を全体 の入口にせざるを得ない、(2)間口が狭いため（2 間が多 い）通り庭側に階段を移す余地が小さい、ことにある。 逆に台所位置と階段を動かした1事例では通り庭が4尺 近く（他は 3 尺）あったのが改善ができた一因である。

1 列 3 段型と 1 列 $3+1$ 段型とは動線の問題が集中す る部分が主屋であるため、改善内容も共通性がある。た だし、別棟仕事場型とそれ以外との間に違いがある。

1 列 3 段型又は 1 列 $3+1$ 段型で 1 室仕事場型、連続 室仕事場型、工房・事務所型（計12事例）のほとんどは、
ミセの間を仕事場の入口とし中の間の通り庭部分を生活 空間の入口としている。通り庭を通って直接奥の部屋に 入れるため1階レベルで仕事場と生活空間の動線上の区 分ができている。さらに階段の位置を通り庭側に移して 2 階へも仕事場を通過せずに行けるようにした事例も 9 事例見られた。このうち 6 事例では同時に 2 階に表の間 と奥の間を結ぶ廊下を追加して2 階中の間の通り抜け動 線を解消している。このように通り庭部分とその上部に 全体の接続空間を集中させる指向が見られる。ただし、 これは間口が 3 間以上の場合が中心であり、特に2.5間 以下の間口で 2 階に廊下を追加したものはない。

一方、1 列 $3+1$ 段型で別棟仕事場型の場合は、奥に ある仕事場へのアプローチのため通り庭に床を張ってい ない事例が 4 事例 (15) あり、仕事場への土足での動線 が居住空間（台所）を通り拔ける状態が残されている。 通り庭と台所を分離した事例（図一 5 、間口は 3 間）が 一つあることは、動線の区分の要求があることを裏付け ているが、他の 4 事例（間口が2.5間以下）ではそのよ うな対応が行なわれなかった。

\section{v）通り庭型プランと改善経歴}

以上述べてきた改善経歴には、通り庭型プランである ための共通性がある。それは、(1)原形のプランには内部 で居室の床を增やす余地があり、それを必要時に活用し てきたこと、(2)動線の中心としての通り庭の性格は引き 継がれ、事例によってはさらにその性格を強める改善を おこなっていること、である。

居室の床を增やす余地は、通り庭の土間部分及び2 階 の吹抜け部分がほほ全事例にあり、さらに「中二階」で あった場合の 2 階の天井が低い一画である。このような 内部空間の利用余地は大多数の事例で活用されている。

通り庭はもともと玄関から他の部屋を通らずに奥の部 屋に入れる動線を保証している。これは多くの併用住宅 での表の仕事場と奥の居住空間の使い分けに適した形式 であり、床が張られた後もその性格を引き継いでいる。 ただし、別棟仕事場型の場合は仕事場のアクセス動線と 台所とが重なる点で他の場合と性格が異なる。

間口に余裕がある場合、階段を通り庭側に移動した事 例があるが、これは動線の中心としての通り庭の性格を さらに強めていると言える。これにより全ての部屋の間 の移動と玄関からのアクセスか他の部屋を通過せずに行 なえるようになっている。このような改善が行なえれば、 工房・事務所型のように仕事場の規模と位置が変化する 場合でも動線の混乱を起こすことが少ない。

このように町家・長屋の原形には併用住宅としての空 間構成の一定の合理性があり、また通り庭をはじめ改善 を加える余地があった。そして、住み手はその特質を生 かしつつ原形の持つ可能性を引き出そうとしてきた。た だし、各住宅型、併用形式、間口の制約条件次第で改善 


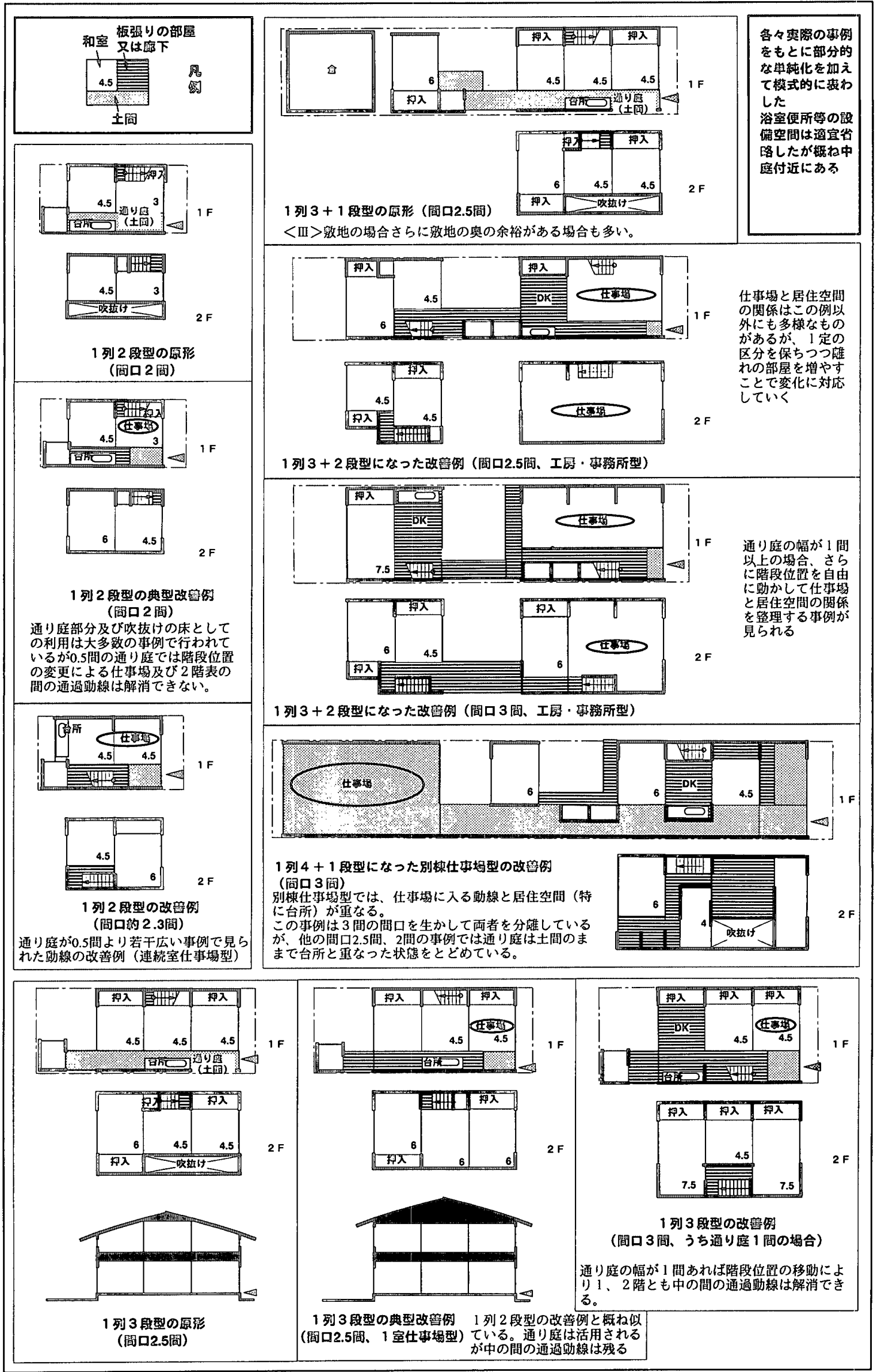

图-5 住宅型ごとの典型改善例 
できた内容も異なる。これを典型的なパターンごとにま とめて図一5に図示した。

\section{（4）改善経歴と住み手の要求}

以上のような改善経歴から読み取れる住み手の要求に ついて考察する。

併用住宅は、限られた空間の中に仕事場と居住空間を 両立させるものであるが、その両立が難しくなった経過 を持つ事例には両者に関する要求の関係がよく表われる。 以前、併用住宅であったものが仕事場を外に移して尃用 住宅化した事例は地区内の18の専用住宅の中にはない。 一方で住宅か転出し仕事場だけが残った事例は 1 事例あ る。また、参考事例として調査した木造アパート（3室 構成）の 7 戸のうち 2 戸でも職住一致世帯から住宅が転 出し仕事場だけが残った経過がある。これらの事例では 居住空間よりも仕事場を当地区に残すことを優先させた わけである。そして、仕事場と居住空間の雨立が困難な 場合への対応を顕著に表わしている事例として、家族が 複数の住宅にまたがって居室を持ったことのある世帯 (4 事例) がある。これは例えば子どもの䕕室を近隣の 別の住宅内に確保し食事は同じ住宅で取るような形式で 行なわれるものである。別住宅の位置は概ね同町内か隣 接町内だが約 $1 \mathrm{~km}$ 離れたものまで見られた。このうち 3 つは 1 列 2 段型の小規模なものだが、離れを持つ住宅型 でも 1 事例ある。

この地区の併用住宅は、住み手の $3 つ の$ 要求に答えて いるものと考えられる。すなわち、この地区に仕事場を 維持すること（「都心仕事場要求」とする）、仕事場と 居住空間の近接（「職住近接要求」）、ある住宅・地域 における家族の安定した生活空間を保つこと（「住み続

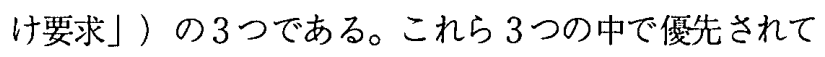
いるのが「都心仕事場要求」である。友禅染色業集積地 区であり都心業務地区に近いという地区の特性から、各 業種とも仕事場をこの地区に保つ必要性は高い。併用住

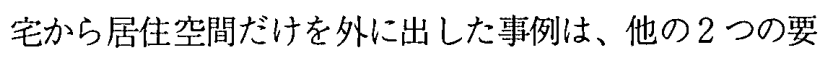
求に対して「都心仕事場要求」を優先せざるを得なかっ たものである。しかし、その事例が比較的少ないのは、 同時に「職住近接要求」実現の必要性が高いからである と考えられる。これを端的に表わすのが、居住空間を複 数の住宅に分散させた 4 つの事例である。そこでは一般 の専用住宅では当然とされる家族の一体的な生活空間よ りも「職住近接要求」を優先させている。居室を別住宅 に移すのは子どもが多く、世帯主等は職住近接を維持す る。聞き取りでも友禅染色業関連業種では「急き物（せ きもの)」と呼ばれる急ぎの注文等に対応するためにも 職住近接が不可欠とする考えが多く聞かれた。このよう に職住近接には不規則な労働時間への対応という側面も 依然残っており、「住み続け要求」が充分に満たされな い事例がある。言いかえると、望ましい生活空間として
の職住近接を実現するという意味では｜住み続け要求」 も同時に実現されることが必要条件になる。

\section{4、まとめ}

(1)敷地、住宅型、仕事場形式から調查地区の併用住宅の 典型的な 3 つのパターンを整理した。

(2)町家・長屋の原形には併用住宅としての空間構成の一 定の合理性と改善余地があった。その可能性は住み手の 改善行為により必要に応じて引き出されてきたが、住宅 型と部屋数、間口による制約条件がある。

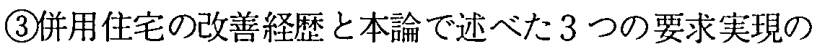
関係について考察した。

(4)住み手の改善行為によりこの地区の併用住宅が維持さ れている。このような営みの維持、発展を市街地整備の 中に位置付けることが一つの課題となる。一方で住宅型 や間口の制約により改善が実現できていない側面につい て改善可能性を検討するという課題があるが、これは別 稿で報告する予定である。

\section{謝辞}

本調査は住み手の日常生活の詳細にまで関わる部分を 含むにもかかわらず、対象地区の皆さんの多大な協力を 得た。記して感謝の意を表したい。

なお、本論文は水方秀也氏（当時京都大学学生）の 1991年度卒業論文の内容を筆者らにより展開させたもの である。

\section{注}

1）文献1の增補分は京都市内の各種の手工業者の併用住宅 を広く取り上げながら「職住混合」の問題を具体的に明 らかにする一方「職・住の分離は必ずしも進歩と言えな い」ことも指摘している。また、文献2)は仕事場が住宅 に及ほす環境上の悪影響が大きい業種を中心に併用住宅 を扱っている。「居住立地限定階層」論は文献3)など。

2) 近年の研究では西陣地域の織屋建住宅の変容の分析があ る(文献4)）。京都市中心部については「商住型市街地」 の整備を検討した研究があるが（文献5)）、既存の併用 住宅など建築レベルの実態や課題は考察の刘象に含まれ ていない。

3）笔者らによる文献6)の報告も京都市について市街地変容 の問題を指摘したものであり、本稿の問題意識の前提と なっている。

4）文献9)のp.104「自力更新力を」一「「まちづくり力」と でも称せるような内容にまで高めて行く対応が個別建て 替六型地区でも必要」であるという記述は、このような 考え方の一例である。

$5 ） 1970$ 年代を中心に文献7をはじめとする研究が多数ある が、1980年代以降はあまり多くなく文献8)、9)が代表的で ある。8)と9)はいずれも改善=建て替えとみなした上での 報告である。

6）今井町については文献10)、金沢市については文献11)、 
12)、13)。

7 ）文献1)第 1 章に紹介される各介調査及び文献14)。

8 ）画地区の町内会とも近年、新規建物の計画による居住環 境悪化の問題に取り組んだことも背景にあり、調査への 町内会の積極的協力を得た。

9）築後28年を経た 1 棟の木造アパートについては併用住宅 としての利用が見られたので参考事例とした（7事例中7 事例で聞き取り、ただし本文で事例数をあげて記述する 中には含んでいない)。

10）文献15)の第三章では、「宅地の型」を13種に分けている。 多様な接道関係や不規則型敷地の整理にはこの程度の類 型数が必要だが、特殊な類型での住宅件数は少ないので 本稿では既存類型の多くを「その他」に入れた。

11）敷地は所有関係によらず土地利用区画としてとらえたの で長屋建ても 1 棟でなく 1 戸1敷地と数えた。「その他」 は、 $1000 \mathrm{~m}^{2}$ を越える寺院の敷地（1例）と小規模で不規 則なもの（2 例）、<四>教地にも奥が不規則形に広がっ たものがあるが、建物主屋部分の教地形状に限れば大き な差はないのでく吕>の範囲に含めた。

12）面積は土地登記簿をもとにした。公図で特定できない形 態の敷地利用のもの3 例は面稌不明。間口は実測ではな く木造建物（非木造の場合は建て替えの前）の間口をもっ て「間口」とした。そのため本稿で言う「間口」より宅 地間口はやや広い。例えば「間口 2 間の敷地」は間口 2 間の建物が成立している敷地のことであり、実際の宅地 間口は $3.8 \mathrm{~m}$ 強になる。モジュールは京間である。奥行き は採取したブランからの推定であり誤差が大きいので大 まかな違いをつかむにとどめた。

13）典型的街区は約 $120 \mathrm{~m} \times$ 約 $120 \mathrm{~m}$ の街区と東西約 $60 \mathrm{~m} \times$ 南 北約 $120 \mathrm{~m}$ の街区。長方形街区の場合はほほ教地奥行きが

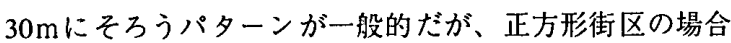
中心の少し手前で止まる敷地が多い。

14）文献1)p.31の図28「町家の間取り、段・列型」に代表さ れる整理方法、文献16)所収の一連の庶民住宅調查以来用 いられている記述方法を踏蹵し、1階平面における間口 方向の部屋数を列、奥行き方向の部屋数を段とする。さ らに離れが加われば○+1段のように表す。なお、正確 には○列○段通り庭型と呼ぶべきだが、調査事例はいず れも通り庭型プランなので「通り庭」を省略して記述し ている。

15） 1 列 4 段は 1 列 3 段と共通性があり、1列 $3+2$ 段、1. 列 $4+1$ 段、 1 列 $4+2$ 段も 1 列 $3+1$ 段と共通点が多 い。そこで、便宜上前者を 1 列 3 段型、後者を 1 列 $3+$ 1 段型に代表させて記述することにした。

16）文献18)pp.37～78の第 2 章「染色業地域における土地利 用および経営状態の分析」によれば友禅染色業集積地域 の中でも調査地区の付近は手描き友禅、引染、整理、染 色補正など手工業性、小規模性の強い業種が多い。
17）平面形態の変化を伴わない各部屋単位の改造、構浩や内 · 外装の補修、衛生等の設備関係の改善も行われているが、 今回は平面の全体構成に関わる改造にしほった。

18）家主が借家の自由な改造を許しているためであるが、こ れはこの地区特有の事情もあり、周辺地域に当てはまる とは限らない。

\section{参考文献}

1）西山外三：日本のすまいI（増補版）、勁草書房、1975 年8月（1987年3月增補）

2）安藤元夫：住工混合地域の都市計画に関する研究、学位 論文、1981年

3）牛見章：大都市地域における住宅立地計画に関する基碟 的研究、学位論文、1971年

4）片方信也、柴田臀：西陣における織元住宅の変容に関す る研究、日本建筑学会計画系論文報告集第 420 号、pp.41 ～48、1991年2月

5）田端修：商住型市街地の研究、学位論文、1992年3月

6）片方信也ほか 4 名：「京都のインナーエリアにおける居 住地の空間構成に関する研究」、日本建筑学会計画系論 文報告集第421号、1991年3月

7）片方信也：既成市街地に扔ける住宅改善、『現代の生活 空間墖 上』、勁草書房、1974年7月

8）佐藤圭二、井沢知旦、市岡佳子：狭小宅地住宅地区にお ける住宅建て替えポテンシャルの低下傾向について、日 本建築学会計画系論文報告集第401号、p p 65７7

9）洪正徳：狭小戸建て・長屋市街地における個別建策行為 についての実態的考察、日本建築学会計画系論文報告集 第413号、pp..95 105、1990年7月

10）足達富士男：歴史的街区保存の可能性、『現代の生活空 間論 下』、勁草曹房、1974年7月

11）王置伸俉、近藤達男：歷史的既成市街地内居住地におけ る宅地間口の収束性について-金沢市におけるケーススタ デイ1、日本建築学会論文報告集第302号、1981年4月

12）玉置伸 悟、近藤達男：歷史的既成市街地内居住地におけ る住宅間口と住宅平面型の関係-金沢市に㧍けるケースス タデイ2、日本建築学会論文報告集第317号、1982年7月

13）玉置伸 俉、近藤達男：歴史的既成市街地内居住地におり る住宅型と設備空間の関係-金沢市におけるケーススタディ 3、日本建築学会論文報告集第336号、1984年2月

14）島村昇、鈴鹿幸雄ほか：京の町家、鹿島出版会、1971年8 月

15）藤井治：都市における古町割制市街地の変容と再編に関 する研究、学位論文、1981年9月

16）西山外三：住宅計面、钫草暳房、1975年8月

17）京都市経済局：京都における工業的市街地の計画に関す る調査研究報告書、1979年3月

(1993 年 7 月 9 日原稿受理, 1993 年 11 月 30 日採用決定) 